\title{
The Relationship between Religious Beliefs and Mental Health of Students
}

\author{
Seyyedeh Zahra seyyed Mirzayi ${ }^{1}$, Mohammad Reza Belyad ${ }^{1} \&$ Masoumeh Zhian Bagheri ${ }^{1}$ \\ ${ }^{1}$ Department of Psychology Karaj Branch, Islamic Azad University, Karaj, Iran \\ Correspondence: Seyyedeh Zahra seyyed Mirzayi, Department of Psychology Karaj Branch, Islamic Azad \\ University, Karaj, Iran. E-mail: z.mirzaee4@gmail.com
}

Received: March 6, 2017

Accepted: March 9, 2017

Online Published: March 31, 2017

doi:10.5539/res.v9n2p69

URL: http://doi.org/10.5539/res.v9n2p69

\begin{abstract}
The aim of this study was to investigate the influence of religious beliefs on mental health of students in Islamic Azad University of Karaj. The research method was regression and Pearson correlation. For this purpose, the population of study was selected from normal undergraduate students of Islamic Azad University in Karaj. Sample of study was included 120 students (60 girls and 60 boys), in academic years of 2015-2016 and they were selected by multi-stage random cluster sampling method. In this study, mental health questionnaire of Goldberg with 28 questions and Baraheni's religious attitude questionnaire with 25 questions were used. The results showed that, there is a significant relationship between religious beliefs and mental health. In the sense that, when religious attitude is more positive, people will have better mental health.
\end{abstract}

Keywords: mental health, religious beliefs, students

\section{Introduction}

The human body is a collection of neuro cells and spirit. So it is required that, all aspects of human life be considered. In fact, when we talk about human as integrated human beings, with all their various features, in addition to environmental and social aspects, emotional, mental and spiritual aspects also should be considered. So religion, as a psychological and spiritual aspect in human, is one of the most important and specific issues and investigating its effect can help to the mental health of human being (Ekhtiari \& Dehghani, 2011). According to the World Health Organization, quality of life can be measured and evaluated based on physical health, mental health, relationships, social relationships and environmental health. The World Health Organization also presents examples for each of these aspects, including:

1) Physical health: Including the ability to perform activities of daily living, dependency rate to medical treatment, strength and fatigue, mobility and agility, pain and discomfort, sleep and rest, capacity to work and activity.

2) Mental health: Including satisfaction and imagination of person from himself and his physical appearance, positive and negative feelings, self-esteem, personal, spiritual and religious beliefs, thinking, learning, memory and concentration.

3) Social relations: Including personal relationships, social support, and sexual activity.

4) Environmental health: Including material and financial resources, freedom, safety, amount of availability and quality of health care, health and social resources, existing opportunities to acquire new information and skills, possibility of recreational activities, health of neighborhood the person lives there and its facilities, health of home environment (Nejati, 2005).

In English, the word religion comes from the Latin root of religio, according to some researchers, first it was used to refer to a superhuman power that wants people behave in a particular manner to avoid the disastrous conclusion. Other researchers concluded that, religio refers to the feeling that exists in people who observe and perceive such a power. This term applied for ritual practices that took place in the shrine of certain Gods. However, the word religio was implied about things people do and deeply felt them or what impacts on their determination, it was something that people obeyed or by it, people were threatened to suffer, were promised reward or were committed to their community (Dehghani, 2007). The first milestone in the psychology of religion, was formed in years (1901-1902M.), with "speeches of Guildford" and "William James" 
(1842-1910M.). These series of lectures were published by the title of "diversity of religious experiences" in 1902.

Mental health is the phenomenon that has been attracted the attention of counselors, psychologists and psychiatrists from long time ago, and it is affected by a set of somatic, social and cognitive factors (Sadeghi, 2007). According to international standards, health does not cover only physical aspects, so the World Health Organization defines health as "a condition in which a person mentally, emotionally and socially is completely healthy" and there isn't any sign of disease and suffering in that person (Campass, 2002). Religion is an important factor that affects health. Religion will change face of the world for a person who has a positive religious attitude and it will change attitude of people about their self-creation and surrounding events. Religious person sees himself under full support and kindness of the Lord, the greatest existing power, thus feel of confident, peace and profound spiritual enjoyment will be gained in that person. He knows God as the source of blessing. So, such a person considers all events, even disasters and tragedies as blessing and a trial from God. He knows himself responsible for bearing the hardships by faith which are not justifiable with wisdom, to achieve development. A person, who has a positive attitude, makes a good relationship based on mutual respect and affection with fellow human beings (Cruz, 2003). Today, among the modern science scientists and psychologists, tendencies are appeared that claim, religion is the best means by which can achieve comfort and mental health. So, investigations have shown a significant and negative correlation between internal religious orientation and anxiety and also there is a positive and significant correlation between external religious orientation and anxiety (Becker, 1982). Kwing (2004) offers at least 10 reasons to explain the relationship between religion and mental health, which are as follows:

1) Religion creates a positive attitude towards the world in a person and will help him against adverse events of life such as lacks or diseases.

2) Religion gives meaning and purpose to person's life. Having meaning and purpose in life, indicates to mental health.

3) Religion enhances one's ability to do things.

4) Religious people with traumatic life events that are not acceptable, are easily compatible.

5) Religion creates hope in people. Hope creates motivation and energy in a person and hopes him to improve his living conditions.

6) Religious people feel more personal freedom than the others. They have less emotional attachments to others.

7) In religious people, sense of control caused by praying; so praying indirectly controls irreversible and catastrophic situations.

8) Religious people use a certain pattern for making decisions. This pattern helps a person to enhance useful decision-making about others and himself and reduces destructive decisions and somehow it reduces stress of life.

9) Religion is the sole responsive source to ultimate questions; especially in emergencies, that science is not able to help people. This is particularly important in serious cases such as the incurable disease.

10) Thus, religious person enjoys more social support. This caused by the individual's connection with religious community, Clergymen, and even God.

According to the proposed issues, purpose of this study is to evaluate the relationship and role of religion in the mental health of students.

\section{Methodology}

The research method in this research is descriptive and correlational. The population of this research are students of Islamic Azad University of Karaj who were studying in academic year of 2016. For sampling, multi-stage random cluster sampling was used. At first, from each college, then from classes, 120 students were selected and research questionnaires were implemented between them. After collecting questionnaires, for data analysis, multivariate regression analysis was performed.

\section{Research Tools}

\subsection{Religious Attitude Questionnaire}

Religious Attitude Questionnaire was designed in 1999 by Baraheni. Validity of test is equal to 0.80, by correlation coefficient test of Allport Vernon and Lindsey. The questionnaire included 25 questions with five scales and with Likert scale it was graded from 0-4. 


\subsection{General Health Questionnaire}

This questionnaire has been introduced by Goldberg and Hilllier (1979), which has 28 questions and contains four scales of: physical (1-7), anxiety disorder and insomnia (8-14), social dysfunction (15-21) and severe depression (22-28). In a study, reliability of tools with test method-retest was calculated about 0.72 to 0.87 . This questionnaire is scored on a Likert scale (Nourbala \& Bagheri, 2004).

\section{Findings}

Table 1. Demographic characteristics of the sample group

\begin{tabular}{ccc}
\hline Characteristics & Frequency & Percent \\
\hline Age & 94 & \\
$20-25$ & 20 & 78.3 \\
$26-30$ & 6 & 16.7 \\
$31-35$ & & 5 \\
Faculty & 16 & \\
Literature and foreign language & 9 & 13.3 \\
Law and political science & 8 & 7.5 \\
Theology & 18 & 6.7 \\
Psychology & 38 & 15 \\
Technical & 31 & 31.7 \\
Science & & 25.8 \\
\hline
\end{tabular}

As can be concluded from Table 1, all statistical samples were 120 people and among them the most age ranges are related to $20-25(78.3 \%)$, and mostly students are from technical faculty $(31.7 \%)$.

Table 2. Mean and standard deviation of mental health and religious attitudes

\begin{tabular}{ccccc}
\hline Scales & Mean & Standard Deviation & Minimum & Maximum \\
\hline Mental health & 52.27 & 16.05 & 25 & 80 \\
Religious attitudes & 38.95 & 12 & 18 & 73 \\
\hline
\end{tabular}

According to Table 2, mean and standard deviation of mental health and religious attitudes were obtained (52.27, $16.05)$ and $(38.95,12.00)$, respectively.

To test this hypothesis, univariate regression statistical method was used. Religious attitude as independent or predictor variable and public health as dependent or criterion variable have entered into the analysis.

Table 3. Summary of regression analysis to predict public health based on religious attitudes

\begin{tabular}{|c|c|c|c|c|c|c|c|}
\hline Index of model & Sum of squares & Degree of freedom & Mean square & $\mathrm{F}$ & $\mathrm{R}$ & $\mathrm{R} 2$ & SE \\
\hline Regression & 16827.22 & 1 & 16827.22 & $* * 143.22$ & 0.74 & 0.54 & 10.83 \\
\hline Residual & 8840.4 & 118 & 117.46 & & & & \\
\hline Index & B & SEB & BETA & $\mathrm{t}$ & $\mathrm{r}$ & & \\
\hline Constant variable & 13.7 & 3.37 & & & & & $* * 4.06$ \\
\hline Religious attitude & 0.99 & 0.08 & 0.74 & $* * 11.96$ & & $* * 0.74$ & \\
\hline
\end{tabular}

$\mathrm{P} \leq 0.01^{* *}, \mathrm{P} \leq 0.05^{*}$. 
According to the obtained results, observed $\mathrm{F}$ is equal to 143.22 in significance level of ( $\mathrm{p}<0.01$ ), and $\mathrm{R} 2$ is equal to 0.74 , and it means that, $74 \%$ of mental health variance is predicted by religious attitudes.

\section{Discussion and Conclusion}

According to the results of study, it was revealed that, statistically there is a significant relationship between religious beliefs and mental health in significance level of 0.01 . The results are consistent with the results of studies by Janbozorgi (2007), Pahlevani et al. (1997), Burgin et al. (1988), Motahari (1999), Javadi Amoli (2012), Marashi (2004), Nazalani (2011), Mohammad Fouladi (2013), Watson et al. (1994), Lindgren (1995), Stewart Vejo (1998), King, Spake and Thomas (1999), Jalilvand et al. (1997), Burgin and Estinch Field (1998).

Many people in their lifetime, experience numerous psychiatric problems in different degrees which caused to changes in various aspects of their health and sometimes their destructive effects can be devastating. Religious beliefs and monotheistic attitudes are factors that can change people's perceptions and point of view regarding problems, and in many cases passing from these problems would be easier. Religious attitudes of people can be influential on their health. However, one of the main ways to prevent and treat mental disorders is emphasizing on religion, divine and monotheism attitudes, but in this study, a significant relationship wasn't observed between religious attitudes and mental health. So, stronger religious beliefs, promote students' mental health and in this regard, more attention should be paid to the teaching of theoretical and practical issues of religion, and creation of deep beliefs in students is essential. When religious attitudes in people are strong and more positive, they will have better mental health. These people are often happier in life and also live longer than others, and they are healthier physically and mentally. Also, people who believe in God and are connected to their God by praying, with good and pious behaviors, physically and mentally are in a good condition, and they can encounter easily with difficulties and tensions of life and they have peace of mind for themselves and others.

\section{References}

Afrooz, G. A., Bolhari, J., Ghorbani, N., Golzari, M., Malekian, M., \& Vaezi, A. (2004). Dreaming, religion and mental health survey of students. Naghd and Nazar publications, 33-34, 6-8.

Arian, K. (1999). The relationship between religiosity and right mental health of Iranians living in Canada $(\mathrm{PhD}$ thesis). Allameh Tabatabaei University in Tehran.

Bahrami, E. H. (202). The relationship between religious orientation, anxiety and self-esteem. Journal of Psychology, 24(4), 327.

Birashk, B., Bakhshayi, N. M., Bayanzadeh, S. A., \& Azerbaijani, T. (2001). Investigating the Role of Religion in experience and ranking of life stresses, depression and anxiety. Abstract of Articles in First International Conference on the Role of Religion in Mental Health, 19.

Esfandabad, S., \& Hasan, N. N. S. (2009). Comparison of quality of life and religious attitudes in addicts and non-addicts in Kerman. Journal of Psychological Studies, Faculty of Education and Psychology, 5(1).

Fouladi, M. (2013). Religious lifestyle, community and religious man. Monthly Magazine of Moaref, the Twenty-Second Year, 3(186), 51-70.

Freud, Z. (1983). Psychology (Mehdi Afshar, trans.). Tehran: Kavian Publications.

Hokmabadi, Z. (2010). The relationship between religious attitudes and general health of students. Supplement of Quran and Medicine, 13(5), 27-34.

Hosseini, A. (1999). Concepts and objectives of mental health. Journal of Mental Health, 1, 13.

Janbozorgi, M. (2007). Religious orientation and mental health. Research Journal of Medical Science Faculty, 31(4), 345-347.

Javadi, A. A. (2012). Mafatih Al-Hayat. Asra Press Center.

Khoramshahi, B. (2010). The study of religion (3rd ed., pp. 94-98). Institute for Humanities and Cultural Studies, Tehran.

Kimiyai, A., Khademian, H., \& Farhadi, H. (2011). Memorizing the Quran and its impact on mental health components. Research Journal of Women and Society, IV, 1-20.

Marashi, A. (2004). Developments in the relationship between mental health and Religion. Journal of Naghd and Nazar, 9(3-4).

Marashi, A. (2004). Religion, general health and longevity. Magazine of Naghd and Nazar, 9(3-4). 
Noorbala, A. A., Bagheri Yazdi, A., \& Mohammad, K. (2008). Validation of General Health Questionnaire with 28 questions as a screening tool for psychiatric disorders in Tehran, 2001. Hakim Research Journal, XI(IV), 47.

Ramezani, V. A., Navabinejad, S., \& Bolhari, J. (2000). Orientation of religion and mental health. Journal of Cognitive Studies at the Islamic University, 12-13, 33-40.

Sadeghi, M. S., Mazaheri, M. A., \& Heydari, M. (2007). Determination of the relationship between parental style of education and religious education with degree of religiosity. Islamic Studies and Psychology, 1, 11-32.

Salarifar, M. R., Azerbaijani, M., \& Rahimi Nejad, A. (2011). Theoretical Foundations of Religious scales. Qom: Sobhan.

Tabrizi, A. (1994). Psychoanalysis crisis (5th ed.). Tehran: Golshan publications.

\section{Copyrights}

Copyright for this article is retained by the author(s), with first publication rights granted to the journal.

This is an open-access article distributed under the terms and conditions of the Creative Commons Attribution license (http://creativecommons.org/licenses/by/4.0/). 